\title{
Erratum to: Forest fire susceptibility mapping in the Minudasht forests, Golestan province, Iran
}

\author{
Zohre Sadat Pourtaghi · Hamid Reza Pourghasemi • \\ Mauro Rossi
}

Published online: 20 August 2014

(c) Springer-Verlag Berlin Heidelberg 2014

\section{Erratum to: Environ Earth Sci}

\section{DOI 10.1007/s12665-014-3502-4}

The authors would like to correct the corresponding author address in the original publication.

The correct version of corresponding author address is given below:

Young Researchers and Elite Club, Nour Branch, Islamic Azad University, Nour, Iran

Email: hm_porghasemi@yahoo.com; hporghasemi@gmail.com

The online version of the original article can be found under doi:10.1007/s12665-014-3502-4.

\section{Z. S. Pourtaghi}

Department of Environment Management Engineering, College

of Natural Resources, Yazd University, Yazd, Iran

H. R. Pourghasemi ( $\square)$

Young Researchers and Elite Club, Nour Branch, Islamic Azad

University, Nour, Iran

e-mail: hm_porghasemi@yahoo.com; hporghasemi@gmail.com

M. Rossi

CNR IRPI, Via Madonna Alta 126, 06128 Perugia, Italy

M. Rossi

Department of Earth Sciences, University of Perugia, Piazza

dell'Universitá 1, 06100 Perugia, Italy 